\title{
Studies on Time and Duration of Flowering, Floral Bud Development and Morphology of Guava (Psidium guajava L.) under Semi-Arid Region of India
}

\author{
Sushil Sharma $^{1 *}$, S.K. Sehrawat ${ }^{1}$ and K.D. Sharma ${ }^{2}$ \\ ${ }^{1}$ Department of Horticulture, ${ }^{2}$ Department of Botany and Plant Physiology, CCS Haryana \\ Agricultural University, Hisar 125004, Haryana, India \\ *Corresponding author
}

\section{A B S T R A C T}

\begin{tabular}{|c|}
\hline Keywords \\
\hline $\begin{array}{l}\text { Guava, Flowering } \\
\text { seasons, Time and } \\
\text { duration of flowering, } \\
\text { Bud development and } \\
\text { flower bearing habit. }\end{array}$ \\
\hline Article Info \\
\hline $\begin{array}{l}\text { Accepted: } \\
28 \text { October } 2017 \\
\text { Available Online: } \\
10 \text { December } 2017\end{array}$ \\
\hline
\end{tabular}

\section{Keywords}

Guava, Flowering seasons, Time and flower bearing habit.
The floral biology of guava cultivars viz. Hisar Safeda, Hisar Surkha, L-49 and Allahabad Safeda was studied at horticulture farm of Department of Horticulture at CCS, Haryana Agricultural University, Hisar. Two flowering seasons, viz., spring (April-May) and autumn (August-September) were observed in all the guava cultivars under semi-arid conditions of Haryana. The duration of flowering varied from 33-41 days in the spring season while it was 38-45 days in the autumn season. The floral bud passed through eight arbitrary stages from dormant to fully opened stage and took 36-42 days to complete all the stages in rainy and winter season respectively. Seventh stage of floral bud was most suitable for emasculation. All the cultivars bore flower solitary or in cymes of 2-3 flowers on the current season growth in the axils of the leaves. The flower size of all the cultivars was found to be significant in both the season i.e. April-May and August-September. However, there was no appreciable difference in the number and size of sepals and petals with regard to cultivars and season of flowering. Greater variation was recorded in the number of stamens in all the cultivars.

\section{Introduction}

Guava occupies an important place in the fruit industry of our country by virtue of its high food value, rich in vitamin-C content, low cost, a pleasant aroma, rich flavour and adaptability to varying conditions of soils (Kahlon et al., 1987). Therefore, it is pertinently referred to as "Poor man's Apple" and "Apple of the Tropics". In India, in terms of area, it ranks after mango, banana and citrus, occupying an area of 0.19 million hectares. However, guava is $5^{\text {th }}$ most important fruit crop in production after banana, mango, citrus and papaya with a total production of 1.68 million tonnes (NHB, 2010). Uttar Pradesh is the largest producer of guava in India and Allahabad has the reputation of producing the world's best guava (Mitra and Bose, 1990). Its importance can be further amplified through the evolution of a variety possessing a combination of big fruit size, attractive red flesh, excellent flavour and seedlessness. This can be consummate through hybridization for which the knowledge of its blossom biology is very useful. Only a few attempts so far have been made to study the blossom biology of guava, the major ones being by Dasarathy at Kodur (1951) and by Balasubrahmanyam (1959) at Annamalai. Some preliminary studies have also been reported by Srivastava (1974) from 
the Govt. Fruit Research Station, Basti (U.P.) and by Dhaliwal and Singla (2002) at Ludhiana. Only a few varieties have been studied and the information available is scanty and conflicting. No detailed work has been done in North India where the climatic conditions differ markedly from those prevailing in South India. Seasonal changes in agricultural and horticultural crops have been well observed since the dawn of civilization but contrary to it detailed and objective studies of different phytophases particularly in fruit trees have lagged behind. Besides stimulating interest and improving habits of observation amongst the lovers of nature such information is of great practical value in a number of field operations. Thus, the knowledge of floral biology of fruit trees is of vital importance for a fruit breeder. The studies on various aspects viz., blooming period, floral bud development, floral morphology, anthesis, dehiscence, pollen germination, mode of pollination and stigma receptivity are essential to initiate a successful breeding programme. Therefore, the present investigations have been carried out to study the floral biology of guava cultivars in Department of Horticulture at CCS, Haryana Agricultural University, Hisar.

\section{Materials and Methods}

The investigation was made during the year 2004-05 on the 10 year old trees of four cultivars viz., Hisar Safeda, Hisar Surkha, Lucknow-49 and Allahabad Safeda, at Experimental Orchard, Department of Horticulture at CCS, Haryana Agricultural University, Hisar. The period between emergence of first and last flower was considered as duration of flowering. The opening of $70 \%$ to $80 \%$ of flowering was an indicative of tree in full bloom stage. The appearance of 20 fresh flowers per tree on a given day was kept as criterion for the beginning and end of flowering season.
Observation on the date of opening of first flower, time of full bloom, date of opening of last flower and duration of flowering were made. Duration of flower bud development was studied by dividing the whole bud development phase (bud swelling to anthesis) into eight arbitrary stages on the basis of the size of the flower bud. The flower buds of the smallest to the largest size in each variety were collected. At three day interval 30 to 60 buds were studied in each variety to find the number of days required for passing from each stage to the next. For flowering habit, 50 flowers of each cultivar were tagged at random on the previous evening and observations were recorded on flowering habit i.e. either the flowers were born on the current season growth in the axils of leaves or terminal vegetative bud of the shoot, flowers were solitary or in cymes of two or three. Average length and breadth were measured in centimeter with the help of digital Vernier caliper just one day prior to opening of flower or fully developed flower bud.

\section{Results and Discussion}

\section{Time and duration of flowering}

Under agro-climatic conditions prevailing in Hisar, the flowering commenced at different dates in different cultivars (Table 1). All the cultivars were found to flower copiously twice a year, i.e. spring (April-May) and again in autumn (August-September). The cultivars Hisar Surkha and Lucknow-49 were the earliest to start flowering in spring and autumn season, respectively. Amongst the cultivars, Hisar Safeda and Hisar Surkha had the longest blooming periods i.e. 41 and 45 days and 38 and 43 days, whereas, Lucknow49 and Allahabad Safeda had the shortest blooming periods i.e. 37 and 40 days and 33 and 38 days during both the season of flowering i.e. spring and autumn, respectively. 
Duration of flowering period in different cultivars varied from 33-41 days during spring flowering season and from 38-45 days in autumn flowering season. All the four cultivars showed longer duration of flowering (38-45 days) during autumn flowering as compared to spring flowering season (33-44 days). The climate during autumn was placid as compared to that of spring flowering season which perhaps drawn out the duration of flowering during winter season (Fig. 1).

\section{Floral bud development}

The floral bud passed through eight distinct stages of development requiring 39-41 days in spring flowering season (Table 2) while 36-40 days in autumn flowering season (Table 3 ) to come to flower. All the cultivars showed same trend of bud development. They differed in numbers of days required for the completion of stage.

After the start of new vegetative flush the flower bud initiation followed simultaneously. The period of initiation of flower bud varied in different cultivars but no substantial variation was observed during both the season i.e. spring and autumn season. The data presented in Table 2 and 3 revealed that there was no palpable difference in the number of days taken for flower bud development in different cultivars of guava for both the seasons of flowering.

The time required for passing from one stage to next stage of bud development also did not indicate much cultivar variability in both the flowering seasons. The number of days required for the completion of one stage to another stage reduced progressively with the advancement of the season in all the cultivars. Starting from the smallest detectable floral buds, the whole period of development can be divided into eight distinct stages (Fig. 2). The first stage buds were about $2.08 \mathrm{~mm}$ to 2.38 mm long different cultivars and protected by two thin green bracteoles (Table 4 and Fig. 2). The second stage bud measured from 7.72 to $7.95 \mathrm{~mm}$ and 7.87 to $8.06 \mathrm{~mm}$ during spring and autumn flowering season, respectively, which reached in 9 to 11 days when they turned conical with well-defined pedicels. In another 5 to 7 days, the buds grew to the third stage which was marked by the appearance of a constriction below the middle (Fig. 2). Here the buds were 12.7 to $14.5 \mathrm{~mm}$ and 11.8 to $14.5 \mathrm{~mm}$ long during spring and autumn season, varying with the cultivars. In the next 4 to 7 days, the buds attained the fourth stage where the constriction became more prominent clearly marking off the ovarian portion below. The length of the buds was 14.43 to $17.97 \mathrm{~mm}$ and 14.16 to $17.21 \mathrm{~mm}$ during spring and autumn season, respectively, with the upper portion becoming plumper.

The buds reached the fifth stage after another 4 to 6 days when the upper or the free part started rounding and developed more rapidly than the lower or the adnate part. They measured 15.03 to $18.98 \mathrm{~mm}$ and 14.39 to $19.50 \mathrm{~mm}$ during spring and autumn season, respectively. The sixth stage was reached in another 4 to 6 days when the buds were 17.49 to $21.45 \mathrm{~mm}$ long in spring and 17.38 to $21.83 \mathrm{~mm}$ during autumn season. The colour of the bud remained green up to this stage.

The buds took 3 to 5 days to attain the seventh stage when they were fully developed. Their size and shape at this stage were characteristic of each cultivar. Length of buds varied from 20.10 to $22.97 \mathrm{~mm}$ and 20.09 to $23.23 \mathrm{~mm}$ during spring and autumn season, respectively. The eighth stage was marked by the splitting of the calyx which took 13 to 26 hours before the flower opening. The calyx splited irregularly or got separated as a cap (Fig. 2). 
Table.1 Time and duration of flowering in different guava cultivars

\begin{tabular}{|c|c|c|c|c|c|c|}
\hline \multirow[t]{2}{*}{ Cultivars } & \multicolumn{2}{|c|}{ Spring Season } & \multirow[b]{2}{*}{$\begin{array}{c}\text { Duration } \\
\text { of Flowering } \\
\text { (Days) }\end{array}$} & \multicolumn{3}{|c|}{ Autumn Season } \\
\hline & $\begin{array}{c}\text { Flowering } \\
\text { Time }\end{array}$ & $\begin{array}{c}\text { Full Bloom } \\
\text { Period }(50 \%-70 \%)\end{array}$ & & $\begin{array}{c}\text { Flowering } \\
\text { Time }\end{array}$ & $\begin{array}{c}\text { Full Bloom } \\
\text { Period } \\
(50 \%-70 \%)\end{array}$ & $\begin{array}{c}\text { Duration } \\
\text { of Flowering } \\
\text { (Days) }\end{array}$ \\
\hline Hisar Safeda & $\begin{array}{c}\text { 10.04.2004 } \\
\text { To } \\
20.05 .2004\end{array}$ & $\begin{array}{c}\text { 15.04.2004 } \\
\text { To } \\
\text { 14.05.2004 }\end{array}$ & 41 & $\begin{array}{c}\text { 12.08.2004 } \\
\text { To } \\
26.09 .2004\end{array}$ & $\begin{array}{c}\text { 21.08.2004 } \\
\text { To } \\
\text { 16.09.2004 }\end{array}$ & 45 \\
\hline Hisar Surkha & $\begin{array}{c}\text { 09.04.2004 } \\
\text { To } \\
\text { 16.05.2004 }\end{array}$ & $\begin{array}{c}18.04 .2004 \\
\text { To } \\
\text { 12.05.2004 }\end{array}$ & 38 & $\begin{array}{c}\text { 09.08.2004 } \\
\text { To } \\
21.09 .2004\end{array}$ & $\begin{array}{c}\text { 18.08.2004 } \\
\text { To } \\
\text { 12.09.2004 }\end{array}$ & 43 \\
\hline Lucknow-49 & $\begin{array}{c}\text { 12.04.2004 } \\
\text { To } \\
\text { 18.05.2004 }\end{array}$ & $\begin{array}{c}\text { 19.04.2004 } \\
\text { To } \\
\text { 12.05.2004 }\end{array}$ & 37 & $\begin{array}{c}\text { 07.08.2004 } \\
\text { To } \\
\text { 16.09.2004 }\end{array}$ & $\begin{array}{c}\text { 15.08.2004 } \\
\text { To } \\
\text { 10.09.2004 }\end{array}$ & 40 \\
\hline Allahabad Safeda & $\begin{array}{c}\text { 13.04.2004 } \\
\text { To } \\
\text { 15.05.2004 }\end{array}$ & $\begin{array}{c}\text { 21.04.2004 } \\
\text { To } \\
\text { 09.05.2004 }\end{array}$ & 33 & $\begin{array}{c}10.08 .2004 \\
\text { To } \\
16.09 .2004\end{array}$ & $\begin{array}{c}\text { 19.08.2004 } \\
\text { To } \\
10.09 .2004\end{array}$ & 38 \\
\hline
\end{tabular}

Table.2 Bud development in guava cultivars during spring flowering season

\begin{tabular}{|c|c|c|c|c|c|c|c|c|c|c|}
\hline \multirow[b]{2}{*}{ Cultivars } & \multirow[b]{2}{*}{$\begin{array}{l}\text { No. of buds } \\
\text { observed }\end{array}$} & \multicolumn{7}{|c|}{ No. of days required for passing from one stage to the other } & \multirow[b]{2}{*}{$\begin{array}{l}\text { Total no. } \\
\text { of days }\end{array}$} & \multirow{2}{*}{$\begin{array}{l}\text { Full Bloom to } \\
\text { Petal-shed } \\
\text { (Days) }\end{array}$} \\
\hline & & 1 to 2 & 2 to 3 & 3 to 4 & 4 to 5 & 5 to 6 & 6 to 7 & 7 to 8 & & \\
\hline Hisar Safeda & 50 & 8 & 9 & 5 & 6 & 4 & 3 & 1 & 36 & 2 \\
\hline Lucknow-49 & 50 & 9 & 9 & 5 & 6 & 5 & 5 & 1 & 40 & 2 \\
\hline Allahabad Safeda & 50 & 8 & 10 & 6 & 4 & 6 & 4 & 1 & 39 & 2 \\
\hline Average & 50.00 & 8.00 & 9.50 & 5.50 & 5.25 & 4.75 & 4.00 & 1.00 & 38.00 & 2.00 \\
\hline
\end{tabular}


Table.3 Bud development in guava cultivars during autumn flowering season

\begin{tabular}{|c|c|c|c|c|c|c|c|c|c|c|}
\hline \multirow[b]{2}{*}{ Cultivars } & \multirow[b]{2}{*}{$\begin{array}{c}\text { No. of buds } \\
\text { observed }\end{array}$} & \multicolumn{7}{|c|}{ No. of days required for passing from one stage to the other } & \multirow[b]{2}{*}{$\begin{array}{l}\text { Total no. } \\
\text { of days }\end{array}$} & \multirow{2}{*}{$\begin{array}{l}\text { Full Bloom to } \\
\text { Petal-shed } \\
\text { (Days) }\end{array}$} \\
\hline & & 1 to 2 & 2 to 3 & 3 to 4 & 4 to 5 & 5 to 6 & 6 to 7 & 7 to 8 & & \\
\hline Hisar Safeda & 50 & 9 & 11 & 6 & 5 & 4 & 4 & 1 & 40 & 2 \\
\hline Hisar Surkha & 50 & 10 & 9 & 7 & 4 & 5 & 3 & 1 & 39 & 2 \\
\hline Lucknow-49 & 50 & 11 & 10 & 6 & 5 & 6 & 4 & 1 & 42 & 2 \\
\hline $\begin{array}{l}\text { Allahabad } \\
\text { Safeda }\end{array}$ & 50 & 9 & 11 & 5 & 7 & 5 & 3 & 1 & 41 & 2 \\
\hline Average & 50.00 & 9.75 & 10.25 & 6.00 & 5.25 & 5.00 & $\mathbf{3 . 5 0}$ & 1.00 & 40.50 & 2.00 \\
\hline
\end{tabular}

Table.4 Floral bud development in guava cultivars during spring and autumn flowering season

\begin{tabular}{|c|c|c|c|c|c|c|c|c|c|}
\hline \multirow{3}{*}{ Cultivars } & \multicolumn{9}{|c|}{ Length (mm.) } \\
\hline & \multicolumn{3}{|c|}{ Stage I } & \multicolumn{3}{|c|}{ Stage II } & \multicolumn{3}{|c|}{ Stage III } \\
\hline & Spring & Autumn & Mean & Spring & Autumn & Mean & Spring & Autumn & Mean \\
\hline Hisar Safeda & 2.02 & 2.37 & 2.21 & 7.95 & 8.06 & 7.96 & 13.90 & 14.50 & 14.17 \\
\hline Hisar Surkha & 2.05 & 2.12 & 2.08 & 7.88 & 7.95 & 7.91 & 13.40 & 12.90 & 13.15 \\
\hline Lucknow-49 & 2.31 & 2.44 & 2.38 & 7.94 & 8.03 & 7.98 & 14.50 & 14.40 & 14.56 \\
\hline Allahabad Safeda & 1.99 & 2.18 & 2.09 & 7.72 & 7.87 & 7.79 & 12.70 & 11.80 & 12.24 \\
\hline Mean & 2.09 & 2.28 & & 7.87 & 7.98 & & 13.61 & 13.40 & \\
\hline $\begin{array}{r}\text { CD at 5\% } \\
\text { Cultivar } \\
\text { Season } \\
\text { Season } X \text { Cultivar }\end{array}$ & $\begin{array}{c}0.108 \\
0.076 \\
0.153\end{array}$ & & & $\begin{array}{l}0.17 \\
0.12 \\
0.24\end{array}$ & & & $\begin{array}{l}0.67 \\
0.47 \\
0.95\end{array}$ & & \\
\hline
\end{tabular}


Fig.1 Weather condition prevailing during spring and autumn season of Flowering

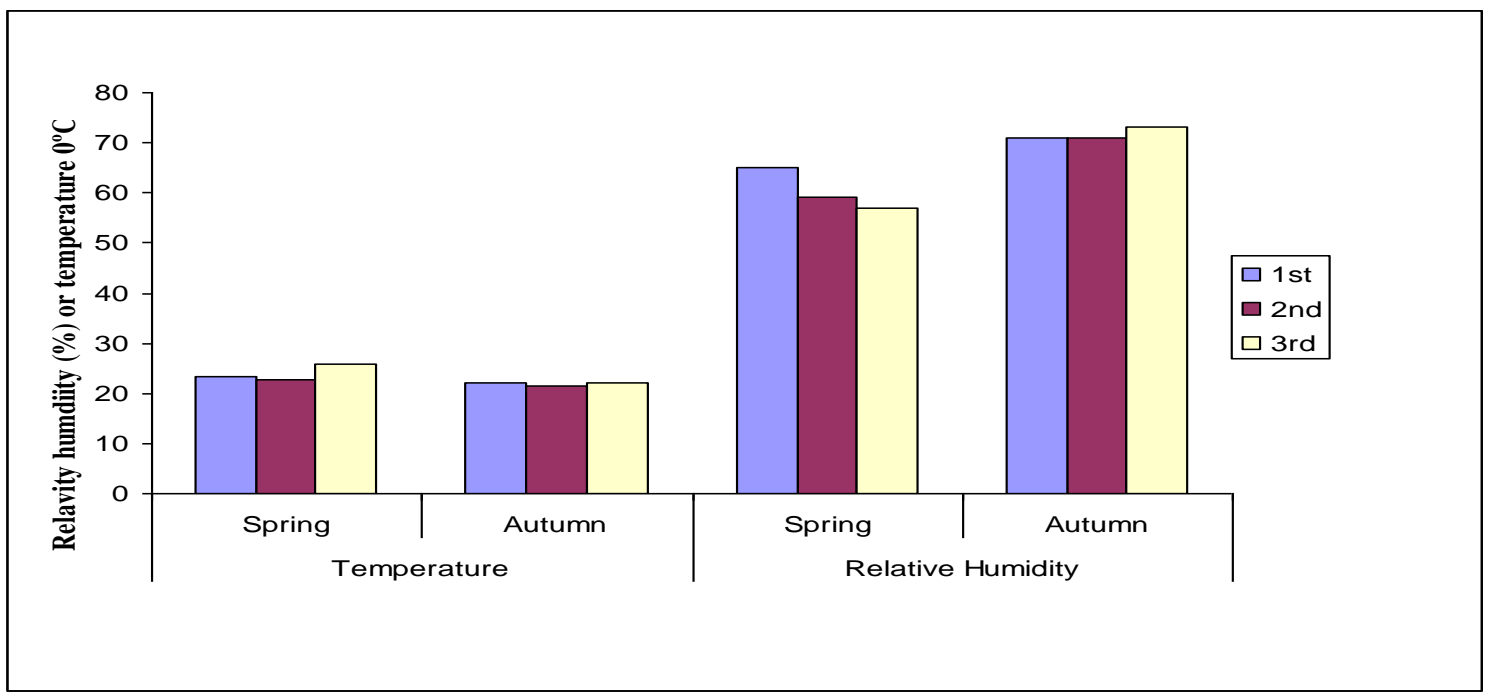

Fig.2 Chronology of stages of bud development in different cultivars of guava
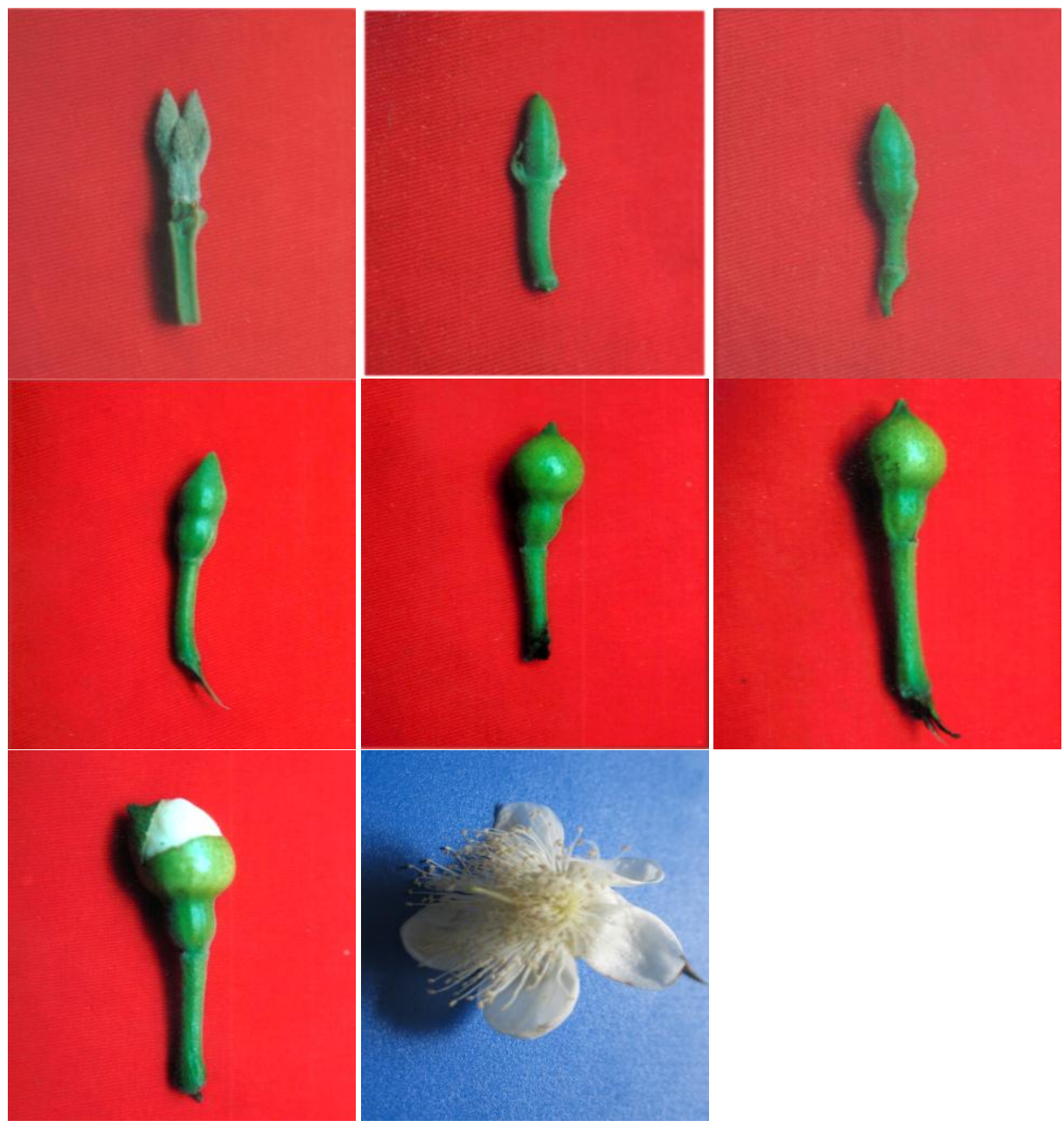
Fig.3 Flowering bearing habit of guava

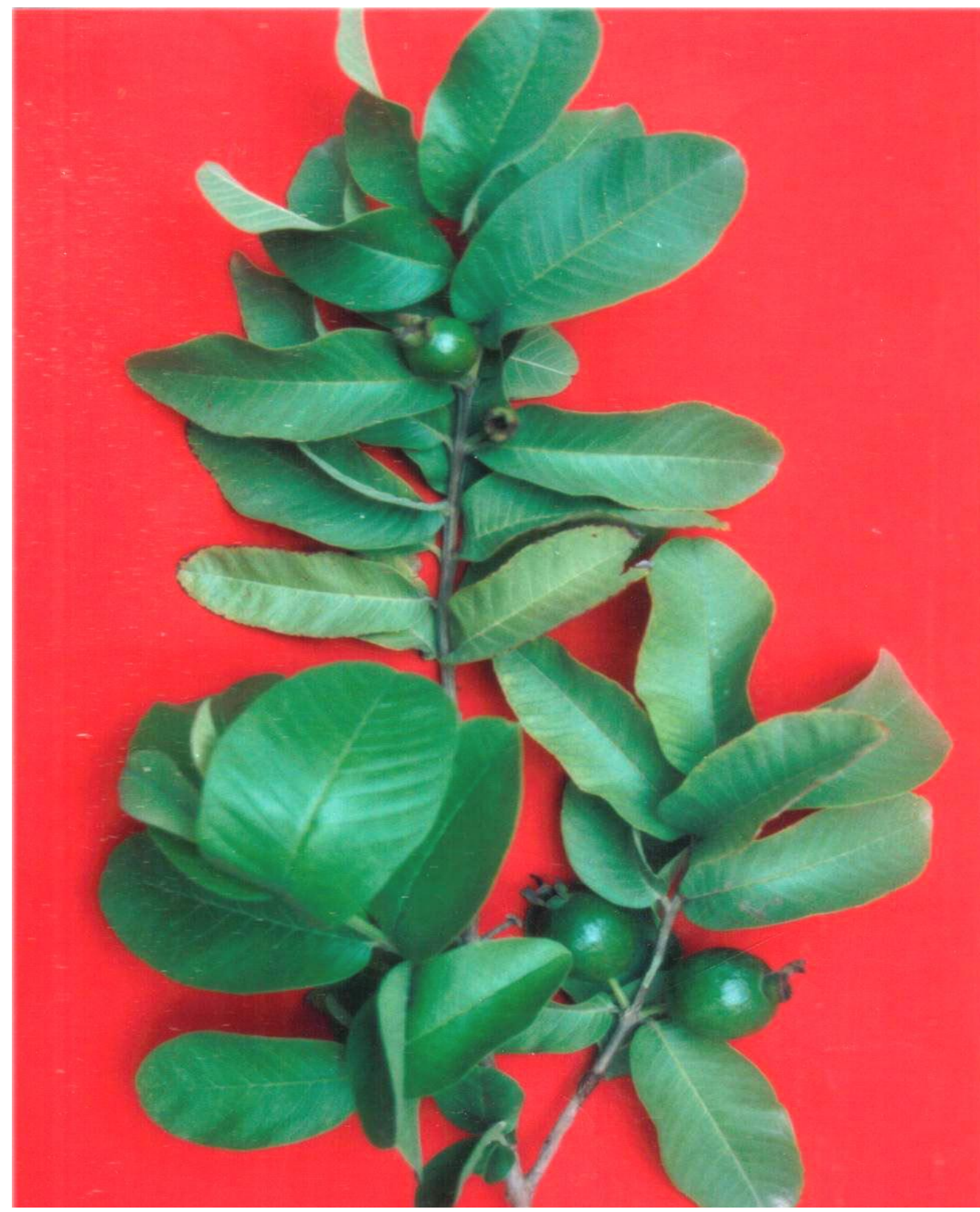

\section{Flower bearing habit}

It was observed that the flowers are borne on the current season growth in the axils of leaves. The flowers are solitary or in cymes of two to three. The shoots bearing the flowers are terminal as well as lateral. Flowers appear on two to three months old shoot. It is hardly possible to forecast whether a shoot would bear flowers or not till the flowers actually emerge. In fact on the same shoot buds in the axils of some leaves produce flowers, while, others do not. It was further observed that axillary flower buds are not produced all over the shoot. These may appear scattered.

The flowering behaviour was the same in all the cultivars studied. 


\section{Floral morphology}

The morphological parameters are discussed under the following sub-heads:

\section{Flower size}

The flower size of all the cultivars was found to differ significantly in both the season (Table 5). However, there was no palpable difference in the number and size of sepals and petals with regard to cultivars and season of flowering. Significant variation was recorded in the number of stamens per flower in all the cultivars (Table 6).

Considerable variations were observed in flower size of different cultivars in both the seasons (Table 5). The seasonal effect on average length and breadth of flowers in all the cultivars was not significant. Amongst different cultivars, Lucknow-49 produced flowers of maximum length $(23.10 \mathrm{~mm})$ which was significantly longer than other cultivars.

The flowers of Hisar Surkha had maximum average breadth $(10.92 \mathrm{~mm})$ which were significantly at par with Lucknow-49 (10.59 $\mathrm{mm})$ and Hisar Safeda $(10.55 \mathrm{~mm})$. The minimum flower breadth was recorded in Allahabad Safeda (09.67 mm) which was significantly lower than other cultivars.

The perusal of season and cultivar interaction revealed that Lucknow-49 produced significantly longer flowers in spring (22.97 $\mathrm{mm})$ and autumn flowering season $(23.28 \mathrm{~mm})$ as compared to other cultivars. The breadth of flowers was significantly at par in Hisar Safeda, Hisar Surkha and Lucknow-49 in both the seasons but significantly broader than Allahabad Safeda $(09.68 \mathrm{~mm}$ in spring and $09.65 \mathrm{~mm}$ in autumn season).

\section{Mode number of sepals, petals and stamens per flower}

The perusal of the data presented in Table 6 indicates that there was no significant difference in the number and size of sepals and petals per flower with regard to cultivars and seasons of flowering i.e. spring and autumn. Mode number of sepals per flower was found to be four in all the cultivars during both the seasons. However, the variation was observed in mode number of petals per flower amongst cultivars. Mode number of petals per flower in Hisar Safeda and Lucknow-49 was 9, whereas, in Hisar Surkha and Allahabad Safeda it was 7 and 10, respectively, in both the seasons. Greater variation was recorded in the mode number of stamens per flower in guava cultivars.

Significantly higher mode number of stamens per flower was found in Lucknow-49 (410) as compared to other cultivars viz. Hisar Safeda (368), Hisar Surkha (393) and Allahabad Safeda (387). However, seasonal effect on mode number of stamens was found non-significant but higher number of stamens was recorded in all the cultivars during spring flowering season as compared to autumn flowering season, except cultivar Hisar Surkha. Lucknow-49 produced significantly higher mode number stamens per flower in spring flowering season (412) as compared to other cultivars, whereas, during autumn season also it produced significantly higher number of stamens as compared to other cultivars, except Hisar Surkha.

The flower size of all the cultivars was found to differ significantly in both the season (Table 5). However, there was no appreciable difference in the number and size of sepals and petals with regard to cultivars and season of flowering. Significant variation was recorded in the number of stamens per flower in all the cultivars (Table 6).

Under agro-climatic conditions prevailing at Hisar, two flowering seasons have been observed i.e. spring (April-May) and autumn (August-September) (Table 1). The results are aligned with the findings of Kahlon et al., (1987), who reported two flowering seasons under Ludhiana conditions. However, these results are in contrast to seasons observed in 
U.P. viz. February and June (Smith, 1934, Gandhi, 1957) and to those in south India viz. January-March and September-October (Balasubrahmanyam, 1959). Temperature is recognized as being the main variable driving the timing of budburst or flowering in woody plants, and different models have been proposed to predict the date of flowering of a population. They all assume that budburst, or flowering, occurs when a critical development threshold $a$ is reached, the stage of development being a sum of daily rates of development (Normand et al., 2002).

Improving synchronization of flowering and the flowering period have been important objectives for breeding and selection programs (Janick and Moore, 1975; Hof et al., 1999; Citadin et al., 2001). Flowering phenology is also affected by the environment (Murfet, 1977; Primack, 1980). Nalawadi et al., (1973) observed that under Dharwar conditions flowering occurred thrice in a year i.e. JuneJuly, September-October and March-April. It is apparent from the time of flowering in guava overall India that it varied with the climatic conditions of a particular region. Duration of flowering period in different cultivars varied from 33-41 days during spring flowering season and from 38-45 days in autumn flowering season. All the four cultivars showed longer duration of flowering (38-45 days) during autumn flowering as compared to spring flowering season (33-44 days). The climate during autumn was placid as compared to that of spring flowering season which perhaps prolonged the duration of flowering during winter season (Fig. 1). Sandhu et al., (1987) also observed that duration of autumn flowering was longer than spring flowering season. In contrary to this, Dubey et al., (2004) reported that there was no significant difference in the period of flowering in guava varieties. It appears that like time of flowering, duration of flowering also is a varietal character predisposed by climatic conditions of a particular region. Thus the time and duration of flowering show a discrepancy with the cultivar and the zone which should be kept in mind while going for hybridization programme. Sehgal and Singh (1967) also observed that guava was found to flower twice a year in April-May and again in August-September. The varieties Chittidar and Red Fleshed were the earliest to start flowering and had the longest flowering periods (36-46 days), whereas, Apple Colour and Seedless were last to flower and also had the shortest flowering periods (27-34 days) during both the seasons. The flowering season was generally longer in autumn (28-46 days) than in spring (27-39 days). Kahlon et.al., (1987) reported that Allahabad Safeda took 43 and 40 days while Lucknow-49, 41 and 38 days for the completion of all stages during autumn and spring flowering under Amritsar conditions, respectively. Similarly, Dasarathy (1951) at Kodur and Nalawadi et al., (1973) under Dharwar condition pragmatic variations in time taken for floral bud development which may be due to locality differences.

However, there was no noticeable difference in the number and size of sepals and petals with regard to cultivars and season of flowering. Kahlon et al., (1987) also reported that there was no appreciable difference in the number and size of sepals and petals. However, Lucknow-49 bore slightly superior size flowers than Allahabad Safeda in both the flowering seasons. Similar findings in various cultivars of guava under Madras and Punjab conditions have been reported by Balasubrahmanyam (1959) and Sandhu et al., (1987), respectively. The differences in size and number of stamens per flower in each cultivar might be attributed to genetic variation. The results are in consonance with those reported by Sandhu et al., (1988) who also observed significant differences between the numbers of stamens per flower in different cultivars.

\section{References}

Balasubrahmanyam, V.R. 1959. Studies on biology of guava ( $P$. guajava L.). Indian J. Hort., 16: 69-75.

Bose, T.K. and S.K. Mitra, 1990. Fruits: Tropical and sub tropical. Naya Porkash, 
206 Bidhan Sarani, Calcutta., India.

Citadin, I., M.C.B. Raseira, F.G. Herter, J. Baptista da selva, 2001. Heat requirement for blooming and leafing in peach. Hort. Sci., 36: 305-307.

Dasarathy, T.B. 1951. The guava (Psidium guajava L.). Madras Agric. J., 38: 320327.

Dhaliwal, G.S. and R. Singla, 2002. Studies on time of anthesis and dehiscence in different genotypes of guava in winter and rainy season crops. Indian J. Hort., 59 (2): 157-161.

Dubey, P.S., M.N., Hoda, J. Singh and S.K. Singh, 2004. Flowering and fruiting of guava varieties during rainy season fruiting. Orissa J. Hort., 32(1): 23-25.

Dwivedi, R., R.K. Pathak and S.D. Pandey, 1991. Effect of season on the vegetative and reproductive attributes of guava fruits cultivar Sardar. Indian Hort., 48 (2): 100104.

Hof I.,Keslser,LCP, Elberse, IAM, Dolstra,O. 1999. A model describing the flowering of single plants, and the heritability of flowering traits of Dimorphotheca pluvalis. Euphytica., 110: 35-44.

Janick, J. and J.N.Moore, 1975. Advances in fruit breeding. West Lafayette: Purdue University Press.

Kahlon, P.S., P.K.Sharma and J.L. Rambadi, 1987. Studies on floral biology of guava (P. guajava L.) cultivar Allahabad Safeda and Lucknow-49. Haryana J. Hort. Sci., 16 (1-2): 65-73.

Murfet, I.C. 1977. Environmental interaction and the genetics of flowering. Annual Review Plant physiol., 28: 253-278.

Nalawadi, W.B., Farook, A.A. Reddy, M.A.N.
Gubbiah and A.S. Nalini, 1973. Studies on floral biology of guava (P. guajava $L$.) var. Lucknow-49. Mysore J. Agric. Sci., 7: 24-37.

Normand, F. R. Habib and J. Chadceuf, 2002. A stochastic flowering model describing as asynchronically flowering set of trees. Annals of Botany., 90: 405-415, 2002.

Primack, R.B. 1980. Variation in the phenology of natural populations of montane shrubs in New Zealand. J. of Ecology., 68: 849862.

Sandhu, A.S., Bains, S.S. and Singh, S.N. 1988. Studies on the floral biology of guava (Psidium guajava L.) under Ludhiana conditions I. Flower bud development, time and duration of flowering and floral morphology. Punjab Hort. J., 27: 203207.

Sehgal, O.P. and R. Singh, 1967. Studies on blossom biology of guava (P. guajava $L$.). I. Flowering habit, flower bud development, anthesis and dehiscence. Indian J. Hort., 24: 118-126.

Sehrawat, S.K., S. Sharma and P.L. Saran, 2008. Pollen grain studies of guava genotypes in winter and rainy season crops. Indian J. of Arid Hort., 2008. Vol. 3(2): 39-41.

Singh, U.P. 1986. Crop regulation studies in guava. Ph.D. Diss., R.A.U., Bihar. 1986.

Smith, W.S. 1934. The guava. Bull. 8, U.P. Dept. Agric. (Fruit Series).

Srivastava, O.P. 1974. Studies on flowering habit, blooming period, anthesis, dehiscence and pollen grain of Psidium guajava L. varieties Apple Colour, Chittidar and Red Fleshed. Prog. Hort., 6: 71-77.

\section{How to cite this article:}

Sushil Sharma, S.K. Sehrawat and Sharma, K.D. 2017. Studies on Time and Duration of Flowering, Floral Bud Development and Morphology of Guava (Psidium guajava L.) under Semi-Arid Region of India. Int.J.Curr.Microbiol.App.Sci. 6(12): 4176-4186.

doi: https://doi.org/10.20546/ijcmas.2017.612.480 